\title{
Effect of Below-Knee Compression Garments on Delayed-Onset Muscle Soreness (DOMS): A Randomized Controlled Laboratory Study With Multi- Parametric Analysis
}

Original Research Article

Keywords:

Posted Date: January 11th, 2021

DOI: https://doi.org/10.21203/rs.3.rs-94383/v2

License: (c) (i) This work is licensed under a Creative Commons Attribution 4.0 International License. Read Full License 


\section{Abstract}

The authors have requested that this preprint be withdrawn due to erroneous posting.

\section{Full Text}

The authors have withdrawn this preprint from Research Square. 